\title{
PENINGKATAN KEMAMPUAN MUSIKAL PESERTA DIDIK MELALUI AKTIVITAS MUSIK KREATIF
}

\begin{tabular}{|c|c|}
\hline & \\
\hline & ${ }^{1}$ Universitas Negeri Jakarta; aldhifirdhani@unj.ac.id \\
\hline $\begin{array}{l}\text { Doc Archive } \\
\text { Submited: 06-11-2020 } \\
\text { Accepted: } 21-12-2020 \\
\text { Published: } 31-01-2021 \\
\text { Keywords } \\
\text { pembelajaran musik; } \\
\text { aktivitas musik kreatif; } \\
\text { kemampuan musikal. }\end{array}$ & $\begin{array}{l}\text { Abstrak } \\
\text { Penelitian ini bertujuan untuk mengetahui keefektifan musik kreatif } \\
\text { untuk meningkatkan kemampuan musikal peserta didik dalam } \\
\text { pembelajaran musik. Metode penelitian menggunakan jenis penelitian } \\
\text { tindakan kelas yang dilakukan dalam } 2 \text { siklus. Penelitian dilakukan di } \\
\text { SMP Sunan Averroes Sleman Yogyakarta selama } 3 \text { bulan. Objek } \\
\text { penelitian adalah peserta didik kelas VIII yang berjumlah } 13 \text { anak. Sumber } \\
\text { data yang digunakan dalam penelitian ini adalah hasil observasi dan hasil } \\
\text { tes kemampuan musikal. Taknik analisis data dilakukan secara kualitatif } \\
\text { yang diidentifikasi untuk melihat hasil pencapaian dan menyempurnakan } \\
\text { di setiap siklusnya. Berdasarkan analisis, hasil penelitian menunjukkan } \\
\text { bahwa aktivitas musik kreatif dapat meningkatkan kemampuan musikal } \\
\text { peserta didik dalam pembelajaran musik. Peningkatan ini dibuktikan } \\
\text { berdasarkan hasil observasi dan perolehan skor kemampuan musikal } \\
\text { peserta didik pada siklus I ke siklus II. Berdasarkan hasil observasi dapat } \\
\text { diketahui bahwa nilai rata-rata kelas kemampuan musikal peserta didik } \\
\text { pada siklus I sebesar 29,5, sedangkan pada siklus II sebesar 40,1. Sehingga } \\
\text { berdasarkan nilai rata-rata tersebut diketahui peningkatan kemampuan } \\
\text { musikal peserta didik sebesar 10,6. Sehingga berdasarkan analisis data } \\
\text { tersebut dapat dikatakan bahwa aktivitas musik kreatif dalam } \\
\text { pembelajaran musik dapat meningkatkan kemampuan musikal peserta } \\
\text { didik. }\end{array}$ \\
\hline $\begin{array}{l}\text { Keywords } \\
\text { music learning; creative } \\
\text { music activity; musical } \\
\text { ability. }\end{array}$ & $\begin{array}{l}\text { Abstract } \\
\text { This study aims to determine the effectiveness of creative music to } \\
\text { improve students' musical abilities in learning music. The research method } \\
\text { uses this type of classroom action research conducted in } 2 \text { cycles. The } \\
\text { research was conducted at SMP Sunan Averroes Sleman Yogyakarta for } \\
\text { three months. The object of the study was } 13 \text { students of class VIII. } \\
\text { Sources of data used in this study are the results of observations and test } \\
\text { results of musical abilities. Data analysis techniques were carried out } \\
\text { qualitatively, which were identified to see the achievement and } \\
\text { improvement results in each cycle. The results showed that creative music } \\
\text { activity could improve students' musical abilities in learning music based } \\
\text { on the analysis. This increase was evidenced by observations and the } \\
\text { acquisition of students' musical abilities in cycle I to cycle II. Based on the } \\
\text { observations' results, it can be seen that the average score of students' } \\
\text { musical ability in cycle I was 29.5, while in cycle II was } 40.1 \text {. Based on } \\
\text { this average value, it is known that the increase in students' musical } \\
\text { abilities is 10.6. So based on this data analysis, it can be said that creative } \\
\text { music activities in learning music can improve students' musical abilities. }\end{array}$ \\
\hline
\end{tabular}




\section{Pendahuluan}

Tidak dapat dipungkiri bahwa Pendidikan memiliki peran penting untuk menentukan kualitas diri seorang individu. Pendidikan dapat mengembangkan potensi-potensi yang dimiliki oleh seorang individu untuk membangun kehidupannya pribadi maupun untuk bangsa dan negaranya. Oleh sebab itu tujuan pelaksanaan pendidikan dalam hal ini proses pembelajaran di dalam kelas perlu diperbaiki agar tujuan pendidikan dapat tercapai dengan maksimal.

Secara umum, tujuan Pendidikan yang harus dilakukan adalah dengan menyediakan lingkungan belajar yang dapat memungkinkan seorang peserta didik untuk mengembangkan bakat dan kemampuannya secara optimal. Dengan adanya hal ini tentu dapat mewujudkan diri dan berfungsi seutuhnya sesuai dengan kebutuhan pribadi dan kebutuhan masyarakat.

Adapun salah satu bidang pendidikan yang dapat mengembangkan potensi peserta didik adalah melalui pembelajaran musik. Pembelajaran musik merupakan salah satu pembelajaran seni yang dilakukan tidak hanya untuk mendidik peserta didik untuk menjadi seniman saja, melainkan juga untuk memaksimalkan kemampuan peserta didik dalam berpikir kritis dan kreatif. Pembelajaran seni juga dipercaya dapat mengembangkan kemampuan intelektual, imajinasi, ekspresi, keterampilan, dan mengapresiasi seni (Pamadhi, 2012).

Pelaksanaan pembelajaran musik yang benar dapat memberikan dampak positif bagi peserta didik. Hal ini ini dikarenakan aktivitas pembelajaran musik dapat merangsang pikiran, sehingga dapat memperbaiki konsentrasi, ingatan, meningkatkan aspek kognitif, fisiologis, dan kecerdasan (Djohan, 2009). Pembelajaran musik juga berpengaruh terdahap perkembangan karakter anak.

Lebih lanjut, Djohan (2009) mengatakan bahwa pembelajaran musik sebaiknya mulai diberikan sejak usia dini, sehingga peserta didik dapat memperoleh stimulasi yang seimbang antara belahan otak kiri dan belahan otak kanan. Penggunaan fungsi kedua belahan otak yang seimbang kelak akan menjadikan manusia yang dapat berpikir logis, intuitif, cerdas, kreatif, jujur dan tajam perasaannya.

Namun berdasarkan kenyataan dilapangan saat ini pembelajaran musik kurang berjalan secara optimal terutama dalam pelaksanaan proses pembelajarannya. Berdasarkan hasil pengamatan guru dalam hal ini yang sekaligus berperan sebagai peneliti, diketahui bahwa respon peserta didik terhadap pembelajaran musik masih kurang. Sebagian besar peserta didik menyatakan bahwa pembelajaran musik yang sudah dilakukan masih terkesan membosankan karena pembelajaran musik yang dilakukan adalah menggunakan media bernyanyi dan aktivitas membaca teks buku saja, sehingga kemampuan musikal yang dimiliki oleh peserta didik juga sangat kurang. Hal ini selain karena strategi pembelajaran musik yang dilakukan kurang tepat dan karena keterbatasan alat penunjang dalam kegiatan bermain musik.

Dalam pembelajaran musik, guru memiliki peran penting dalam menentukan tercapainya tujuan pembelajaran. Dalam hal ini tugas guru selain membimbing peserta didik, juga memiliki peran untuk memberikan motivasi kepada peserta didik agar selalu semangat dalam pembelajaran musik. Penggunaan strategi pembelajaran yang tepat diharapkan dapat meminimalisir masalahmasalah yang terjadi selama proses pembelajaran berlangsung. Sehingga dalam hal ini guru perlu memikirkan bagaimana proses pembelajaran yang inovatif dapat diaktualisasikan secara sistematis dan efektif sehingga dapat menciptakan budaya belajar yang dapat mengembangkan kemampuan-kemampuan peserta didik (Sriningsih, 2018).

Dengan adanya permasalahan ini, perlu ada upaya untuk meningkatkan mutu pendidikan melalui proses pembelajaran dan penelitian. Adapun salah satu upaya yang akan dilakukan untuk memperbaiki kualitas pembelajaran yang ada di dalam kelas adalah dengan mengubah strategi pembelajaran yang digunakan. Berdasarkan hasil studi literatur, untuk memperbaiki keadaan tersebut perlu mencoba menerapkan strategi pembelajaran yaitu menggunakan aktivitas musik kreatif dalam pembelajaran musik.

Aktivitas musik kreatif merupakan salah satu aktivitas musik yang terfokus pada masalah mendasar seperti cara berfikir tentang musik baru, sehingga memungkinkan mencapai tujuan metode dan komposisional tertentu. Aktivitas musik ini dapat tercapai melalui keterampilan improvisasi, pengembangan memori, dan konsentrasi yang akan dipraktikkan oleh peserta didik.

Sarry (1999) mengatakan bahwa musik merupakan suatu keberlangsungan suara. Segala bentuk suara dipercaya sebagai musik, seperti halnya suara binatang, suara alam, maupun suara dari benda. Dari suara-suara tersebut kemudian 
disusun secara rapi hingga menjadi sebuah komposisi musik. Dalam pembuatan komposisi musik tersebut diperlukan eksperimen yaitu melalui aktivitas musik. Selain itu, langkahlangkah pembelajaran musik kreatif didasarkan pada aktivitas yang berfokus pada masalah dasar pemikiran musik baru melalui kegiatan-kegiatan yang menyenangkan menggunakan elemenelemen musik. Aktivitas ini dilakukan untuk meningkatkan memori, keterampilan improvisasi, serta konsentrasi melalui ansambel musik.

Pada pembelajaran musik yang menggunakan model kreatif terutama tujuan akhir berupa hasil komposisi musik kreatif dapat meningkatkan apresiasi, pengetahuan, dan keterampilan. Adanya kegiatan ini dapat dijadikan sebagai salah satu upaya bagi peserta didik dalam menemukan inspirasi, ide, dan gagasan sebagai dasar dalam menciptakan suatu bentuk musik sesuai dengan tingkat perkembangan masing-masing peserta didik (Sukmayadi \& Purnama, 2016).

Adapun dalam aktivitas musik kreatif terdapat empat strategi yaitu mengenal potensi bunyi, mengenal pola irama, mengenal komunikasi musikal, dan mengenal pola susunan (komposisi) musik (Djohan \& Tyasrinestu, 2010). Pada tahapan mengenal potensi bunyi, dilakukan untuk membuka wacana imajinasi anak bahwa semua suara disekitar tubuh dan alam berpotensi sebagai sumber bunyi (alat musik). Pada tahapan ini siswa diperkenalkan pada materi tentang banyaknya sumber bunyi yang jika disusun dengan baik akan menjadi suatu bentuk musik baru. Pada tahapan ini sumber bunyi yang bisa digunakan tidak hanya dari alat-alat musik saja, melainkan segala sesuatu yang dapat menghasilkan bunyi yang dapat disusun menjadi musik.

Pada tahapan mengenal pola irama, setelah anak mengenal potensi bunyi, anak dapat mulai mengenal irama dan tempo. Pada tahapan ini anak akan diperkenalkan dengan penyusunan irama musik. Dalam penyusunan irama musik ini kemudian akan diberikan pengetahuan materi tentang unsur-unsur musik seperti bunyi, irama, tempo, timbre, dan dinamika.

Unsur bunyi merupakan unsur dasar dalam membuat karya musik, dalam bunyi didapati nada (tinggi rendahnya bunyi), melodi (rangkaian nada-nada), meskipun dalam musik juga membutuhkan sunyi atau tidak ada bunyi. Unsur irama merupakan gerak musik yang berjalan teratur yang tidak tampak dalam lagu tetapi dapat dirasakan setelah lagu itu dialunkan. Unsur tempo adalah ketukan konstan yang mengikat bunyi menjadi satu kesatuan detak. Dalam hal ini tempo juga dapat diartikan sebagai rata-rata satuan waktu pada saat sebuah musik dimainkan yang menggambarkan kecepatan musik tersebut. Dalam bermain musik tidak boleh sampai mendahului atau lebih lambat dari tempo (Swanwick, 1999).

Unsur timbre dapat disebut dengan warna suara. Timbre sangat dipengaruhi oleh sumber bunyi dan cara menggetarkan atau membunyikannya. Misalnya saja dua alat musik seperti gitar dan biola dimainkan bersama-sama pada nada dasar sama, maka akan tetap dapat membedakan mana suara gitar dan mana suara biola karena kedua alat memiliki warna suara yang berbeda. Sedangkan unsur yang terakhir adalah unsur dinamika. Unsur dinamika merupakan aspek musik yang terkait dengan tingkat kekerasan bunyi, atau gradasi kekerasan dan kelembutan suara musik. Adapun simbol musik yang menjelaskan tentang dinamika musik seperti piano (lembut) dan forte (keras) (Swanwick, 1999).

Setelah tahap mengenal pola irama, tahap selanjutnya dalam aktivitas musik kreatif adalah tahap mengenal komunikasi musikal. Dalam tahapan ini diharapkan anak belajar bekerjasama menyusun musik dengan tempo, irama, warna suara, dan dinamika secara bersama-sama. Sumbangsih ide pembuatan musik setiap anak disini diharapkan dapat membuat musik yang akan dibuat menjadi lebih indah dan pola musik lebih kreatif.

Adapun tahap terakhir dalam aktivitas musik kreatif adalah tahap mengenal pola susunan (komposisi) musik, yaitu mengenalkan dan menambah wacana pada anak tentang musik yang sudah terpola. Dalam tahapan ini guru memberikan arahan kepada siswa tentang bagaimana penyusunan komposisi yang baik dan benar.

Berdasarkan uraian terkait strategi pembelajaran yang dilakukan dalam penelitian tindakan ini, diharapkan dapat meningkatkan respon peserta didik dalam proses pembelajaran musik. Sehingga dengan meningkatnya respons peserta didik terhadap proses pembelajaran dapat meningkatkan pula kemampuan musikal yang dimiliki oleh masing-masing peserta didik. Dalam kata lain, keberhasilan pelaksanaan strategi pembelajaran ini diharapkan dapat meningkatkan kualitas pengajaran yang ada di sekolah tempat penelitian berlangsung. Selain itu, hasil dari penelitian ini diharapkan dapat 
dijadikan suatu rujukan oleh guru lain untuk meningkatkan kualitas proses pembelajaran yang ada di sekolah lain dengan menggunakan strategi pembelajaran melalui aktivitas musik kreatif.

\section{Metode}

Metode penelitian yang digunakan adalah jenis penelitian tindakan kelas. Penelitian Tindakan kelas ini dilaksanakan di SMP Sunan Averroes Sleman Yogyakarta dari bulan maret mei 2017 (semester genap tahun ajaran 20162017). Subjek penelitian yang digunakan adalah seluruh peserta didik pada kelas VIII dengan jumlah peserta didik 13 anak. Penelitian ini dilakukan dalam 3 siklus, dimana setiap siklusnya terdiri dari 4 tahapan yakni: tahap perencanaan/planning, tahap pelaksanaan/action, tahap observasi/observation, dan tahap refleksi/reflection.

Sumber data dalam penelitian ini dikumpulkan menggunakan teknik observasi dan pemberian tes yang berupa tes kemampuan musikal untuk mengetahui seberapa tinggi kemampuan musik masing-masing peserta didik yang melakukan proses pembelajaran musik menggunakan aktivitas musik kreatif. Adapun pengukuran kemampuan musikal peserta didik dilakukan melalui pengembangan instrumen yang dibuat oleh Edwin Gordon yaitu Musical Apptitude Profile (1967). Berikut kisi-kisi instrumen tes kemampuan musikal dapat dilihat pada Tabel 1.

Table 1. Kisi-kisi instrumen tes kemampuan

\begin{tabular}{cll}
\multicolumn{2}{c}{ musikal } \\
\hline Aspek & \multicolumn{1}{c}{ Indikator } & Nomor Soal \\
\hline \multirow{3}{*}{ Tonal } & Membedakan Nada. & $1,2,3,4$ \\
\cline { 2 - 3 } Imagery & Membedakan Melodi & $5,6,7,8$, \\
\cline { 2 - 3 } & Menirukan Melodi & $9,10,11,12$ \\
\cline { 2 - 3 } & Membedakan Harmoni & $13,14,15,16$ \\
\hline Rhythm & Membedakan Ritme & $17,18,19,20$ \\
\cline { 2 - 3 } Imagery & Menirukan Ritme & $21,22,23,24$ \\
\cline { 2 - 3 } & Menentukan Tempo & $25,26,27,28$ \\
\hline
\end{tabular}

Berdasarkan Tabel 1 tersebut, dapat diketahui bahwa instrumen tes kemampuan musikal ini dikembangkan berdasarkan 2 aspek penilaian, yaitu Tonal Imagery dan Rhythm Imagery. Pada tonal imagery terdapat empat indikator yaitu membedakan nada, membedakan melodi, menirukan melodi, dan membedakan harmoni dengan jumlah soal 16 nomor. Sedangkan pada rhythm imagery terdapat tiga indikator yaitu membedakan ritme, menirukan ritme, dan menentukan tempo dengan jumlah soal 12 nomor. Adapun dalam menentukan skor perolehan masing-masing peserta didik dapat dilihat berdasarkan Tabel 2 .

Table 2. Skala tingkat instrumen tes kemampuan musikal

\begin{tabular}{cc}
\hline Jawaban & Skala Skor \\
\hline Salah & 1 \\
\hline Benar & 2 \\
\hline
\end{tabular}

Berdasrkan Tabel 2 tersebut, dapat diketahui terdapat dua tingkatan penilaian yang menggunakan skala rating, yaitu salah dan benar. Adapun setelah data diperoleh, langkah selanjutnya adalah melakukan analisis data. Hasil perolehan data tersebut yang berupa angka kemudian diambil rata-rata kelasnya, setelah itu dianalisis secara kualitatif dengan melihat penyempurnaan yang sudah dilakukan pada setiap siklusnya. Adapun dugaan sementara tindakan dalam penelitian ini adalah skor ratarata yang diperoleh kelas mencapai kriteria "Sangat Tinggi" dan "Tinggi". Sehingga tindakan yang berupa aktivitas musik kreatif dapat meningkatkan kemampuan musikal peserta didik dalam pembelajaran musik.

Setelah pelaksanaan tahap action pada setiap siklusnya, diperoleh data-data yang terkumpul pada tahapan evaluasi dan hasil observasi. Data hasil observasi dilakukan untuk mengetahui bagaimana peningkatan respons peserta didik terhadap proses pembelajaran yang sudah dilakukan. Sedangkan data hasil penilaian tes kemampuan musikal dilakukan untuk mengetahui bagaimana peningkatan kemampuan musikal peserta didik. Adapun untuk mengetahui peningkatan hasil tes kemampuan musikal peserta didik tersebut, data dianalisis secara kuantitatif menggunakan rumus berikut:

$$
R K=\frac{J S T}{J S}
$$

Keterangan:

RK : Rata-Rata Kelas

JST : Jumlah Skor Total

JS : Jumlah Siswa

\section{Hasil dan Pembahasan}

Setelah data nilai rata-rata kelas diperoleh, data kemudian dianalisis secara kualitatif. Adapun beberapa hal yang perlu diperhatikan dalam hasil penelitian tindakan kelas ini diantaranya adalah: (1) apa saja yang sudah dilakukan, (2) apa saja kendala yang dihadapi selama proses pelaksanaan berlangsung, (3) apa saja faktor penyebab selama proses pelaksanaan berlangsung, (4) apa dampak yang ditimbulkan dari faktor penyebab tersebut, (5) apa solusi yang 
diberikan untuk meminimalisir faktor penyebab, dan (6) bagaimana hasil setelah dilakukan solusi/upaya pemecahan permasalahan selama proses tindakan berlangsung.

\section{Hasil Siklus I \\ Tahap Perencanaan}

Pada tahap perencanaan ini hal yang dilakukan ialah dengan menyusun timeline pelaksanaan yang dilakukan. Beberapa kendala yang dihadapi dalam menyusun timeline ini adalah sulitnya menyesuaikan jadwal pembelajaran dengan agenda kegiatan pondok dimana sekolah tempat penelitian merupakan Boarding School.

Setelah timeline pelaksanaan tersusun, yang dilakukan berikutnya adalah menyusun instrumen pengukuran tes kemampuan musikal. Adapun beberapa kendala yang dihadapi adalah terkait proses validasi instrumen penelitian oleh pakar. Proses validasi tersebut terselesaikan melebihi waktu yang sudah disusun pada timeline penelitian.

\section{Tahap Pelaksanaan}

Pada proses pelaksanaan ini pembelajaran belum berlangsung secara optimal. Sebagian besar peserta didik masih terkendala dalam memahami praktik-praktik aktivitas bermain musik mengggunakan aktivitas musik kreatif. Beberapa peserta didik kurang terbiasa dalam melakukan gerak-gerak melalui game musikal berdasarkan proses tahapan dalam akktivitas musik kreatif.

\section{Tahap Observasi}

Pada tahap observasi, didapatkan hasil bahwa sebagian besar peserta masih kaku dalam mempraktikan aktivitas musik kreatif. Selain itu beberapa kendala yang dihadapi adalah terkait pemahaman pengaplikasian teori musik dalam bentuk praktik. Sedangkan hasil kemampuan musikal peserta didik juga masih belum maksimal. Adapun hasil rata-rata perolehan skor kemampuan musikal pada siklus I dengan rincian perolehan skor masing-masing peserta didik dapat dilihat pada Tabel 3.

Table 3. Perolehan tes kemampuan musikal siklus I

\begin{tabular}{cc}
\hline Kode Subjek & Perolehan Skor \\
\hline SA1 & 27 \\
\hline SA2 & 32 \\
\hline SA3 & 32 \\
\hline SA4 & 26 \\
\hline SA5 & 29 \\
\hline SA6 & 34 \\
\hline
\end{tabular}

\begin{tabular}{cc}
\hline SA7 & 27 \\
\hline SA8 & 27 \\
\hline SA9 & 33 \\
\hline SA10 & 30 \\
\hline SA11 & 26 \\
\hline SA12 & 30 \\
\hline SA13 & 30 \\
\hline Rata-Rata & $\mathbf{2 9 , 5}$ \\
\hline
\end{tabular}

Berdasarkan Tabel 3 tersebut dapat diketahui bahwa rata-rata skor tes kemampuan musikal kelas sebesar 29,5. Adapun lebih lanjut ditentukan kriteria penilaiannya berdasarkan kriteria penilaian pada tabel 4 .

Table 4. Kriteria penilaian rerata skor

\begin{tabular}{cl}
\hline Nilai Rata-Rata & Kriteria \\
\hline $0-11$ & Sangat Rendah \\
\hline $12-23$ & Rendah \\
\hline $24-35$ & Sedang \\
\hline $36-47$ & Tinggi \\
\hline $48-55$ & Sangat Tinggi \\
\hline
\end{tabular}

Berdasarkan tabel tersebut hasil perolehan yang didapatkan dari rata-rata skor kelas dapat dikategorikan "Sedang". Sehingga dengan adanya perolehan ini, perlu dilakukan upaya kembali untuk memberikan action agar nilai kemampuan musikal peserta didik dapat meningkat.

\section{Tahap Refleksi}

Berdasarkan hasil analisis pada tahap pelaksanaan dapat diidentifikasi beberapa kendala yang dialami oleh peserta didik, diantaranya adalah belum seimbangnya kemampuan psikomotor peserta didik dalam melakukan praktik pada tahap mengenal pola irama. Selain itu, kendala yang dihadapi adalah masih kurangnya kemampuan konsentrasi peserta didik dalam menerima materi. Lebih lanjut hal yang tidak kalah penting adalah kurangnya pemahaman unsur-unsur musik yang dimiliki peserta didik, sehingga dalam praktik tahap mengenal susunan musik (komposisi) masih sangat terkendala. Dengan masih adanya kendala-kendala tersebut, penelitian kemudian dilanjutkan pada siklus II, dengan harapan kemampuan musikal peserta didik dapat lebih meningkat lagi, sehingga pembelajaran musik dapat berjalan lebih efektif.

\section{Hasil Siklus II \\ Tahap Perencanaan}

Pada tahap perencanaan siklus ke II ini, telah disadari terkait permasalahan-permasalahan 
apa saja yang terjadi pada siklus I. Hal ini mendorong agar harus ada perbaikan pada semua tahapan-tahapan dalam pembelajaran musik yang menggunakan aktivitas musik kreatif, terutama dalam hal memberikan penjelasan terkait unsurunsur musik dengan cara yang lebih mudah dipahami oleh peserta didik, salah satunya adalah melalui permainan-permainan sederhana. Dengan adanya solusi tersebut, diharapkan tidak ada lagi hambatan yang dialami oleh peserta didik dalam menerapkan aktivitas musik kreatif dalam pembelajaran musik.

\section{Tahap Pelaksanaan}

Mengacu pada kendala-kendala yang dihadapi selama siklus I, telah dilakukan sebuah upaya agar kendala pada siklus I dapat diminimalisir, sehingga perolehan skor kemampuan musikal peserta didik dapat lebih meningkat. Selain itu respons peserta didik dalam pembelajaran musik melalui aktivitas musik kreatif dapat meningkat.

\section{Tahap Observasi}

Pada tahap observasi siklus II, didapatkan hasil bahwa peserta sudah lebih luwes dan enjoy dalam mempraktikan aktivitas musik kreatif. Selain itu beberapa kendala yang dihadapi pada siklus I seperti pemahaman pengaplikasian teori musik dalam bentuk praktik sudah tidak terlihat lagi, peserta didik lebih mudah memahami melalui aktivitas-aktivitas seperti permainanpermainan sederhana, seperti permainan do mi ka do dan donal bebek (permainan anak masyarakat jawa). Sedangkan pada hasil kemampuan musikal peserta didik mengalami peningkatan. Adapun hasil rata-rata perolehan skor kemampuan musikal pada siklus II dengan rincian perolehan skor masing-masing peserta didik dapat dilihat pada Tabel 5.

Table 5. Perolehan tes kemampuan musikal siklus II

\begin{tabular}{cc}
\hline Kode Subjek & Perolehan Skor \\
\hline SA1 & 44 \\
\hline SA2 & 40 \\
\hline SA3 & 40 \\
\hline SA4 & 39 \\
\hline SA5 & 43 \\
\hline SA6 & 39 \\
\hline SA7 & 41
\end{tabular}

\begin{tabular}{cc}
\hline SA8 & 40 \\
\hline SA9 & 36 \\
\hline SA10 & 42 \\
\hline SA11 & 34 \\
\hline SA12 & 43 \\
\hline SA13 & 40 \\
\hline Rata-Rata & $\mathbf{4 0 , 1}$
\end{tabular}

Berdasarkan Tabel 5 tersebut dapat diketahui bahwa rata-rata skor tes kemampuan musikal kelas siklus II sebesar 40,1. Adapun lebih lanjut penentuan kriteria penilaiannya sebagaimana pada Tabel 4 lalu. Berdasarkan tabel 6 tersebut hasil perolehan yang didapatkan dari rata-rata skor kelas dapat dikategorikan "Tinggi".

\section{Tahap Refleksi}

Berdasarkan hasil analisis pada tahap pelaksanaan siklus II ini terdapat peningkatan yang sebelumnya pada kriteria "Sedang" berubah menjadi kriteria "Tinggi". Dengan kata lain, dapat diketahui bahwa pelaksanaan proses pembelajaran musik menggunakan aktivitas musik kreatif dapat meningkatkan kemampuan musikal peserta didik. Hal ini tentu dapat membuktikan benarnya dugaan sementara dari tindakan/perlakuan yang diajukan. Adapun berdasarkan hasil observasi terhadap respon peserta didik dalam pembelajaran musik juga sangat positif dan sangat antusias dalam melakukan setiap proses pembelajarannya.

\section{Kesimpulan}

Berdasarkan hasil analisis pada masingmasing siklus dapat diketahui bahwa aktivitas musik kreatif dalam pembelajaran musik dapat meningkatkan kemampuan musikal peserta didik. Hal ini dibuktikan adanya peningkatan skor ratarata pada siklus I dan siklus II. Pada siklus I ratarata kelas adalah sebesar 29,5 dengan kriteria penialaian adalah "Sedang". Sedangkan pada siklus II skor rata-rata kemampuan musikal peserta didik adalah sebesar 40,1 dengan kriteria penilain adalah "Tinggi”. Berdasarkan hasil nilai rata-rata tersebut diketahui peningkatan sebesar 10,6. Selain itu, berdasarkan observasi yang dilakukan dapat diketahui bahwa respon peserta didik terhadap pembelajaran musik menggunakan aktivitas musik kreatif sangat positif dan sangat antusias.

\section{Referensi}

Djohan. (2009). Psikologi Musik. Yogyakarta: Best Publisher.

Djohan, \& Tyasrinestu, F. (2010). Model Pembelajaran Musik Kreatif bagi Pengembangan 
Kreativitas Anak di Wilayah DIY. Yogyakarta.

Gordon, E. (1967). The Musical Aptitude Profile. Music Educators Journal, 56(3), 52-54. Retrieved from https://journals.sagepub.com/doi/abs/10.2307/3390915?journalCode=mejc

Pamadhi, H. (2012). Pendidikan Seni: Hakikat Kurikulum Pendidikan Seni, Habitus Seni, dan Pengajaran Seni Anak. Yogyakarta: UNY Press.

Sáry, L., \& Földes, I. (1999). Creative Music Activities. Pecs: Jelenkor.

Sriningsih, E. (2018). Peningkatan Hasil Belajar Seni Musik Siswa Menggunakan Strategi Pembelajaran CTL (Contextual Teaching Learning). JURNALISTRENDI: Jurnal Linguistik, Sastra, Dan Pendidikan, 3(2), 256-268. Retrieved from http://ejournal.unwmataram.ac.id/trendi/article/download/86/46

Sukmayadi, Y., \& Purnama, A. (2016). Model Pembelajaran Komposisi Musik Sekolah Melalui Pemanfaatan Perkakas Tangan. Resital: Jurnal Seni Pertunjukan, 17(3), 158-169. Retrieved from http://journal.isi.ac.id/index.php/resital/article/view/2225

Swanwick, K. (1999). Teaching Music Musically. London: Routledge. 